\title{
Once upon a time... smoking began its decline among women in Spain
}

\author{
Joan R. Villalbí ${ }^{1,2}$, Esteve Fernàndez ${ }^{3,4}$
}

\section{Dear Editor,}

The epidemiology of smoking is a changing topic: it is a dynamic process that was characterized in a "descriptive model" more than two decades ago by Lopez et al..$^{1}$ and recently updated by Thun et al., ${ }^{2}$ underlying its gender specificity. In Spain, the trend in the smoking prevalence by sex has been well characterized by reconstructing the historical prevalence rates from recent surveys ${ }^{3}$. In men, smoking prevalence was already above $50 \%$ in mid-1990 and slowly increased up to $60 \%$ in the 1970 s, remaining stable up to 1980 , when it started to decrease to $40 \%$ in 2000 , and to $27.9 \%$ in 2011 . In women, smoking prevalence was very low in 1940, slowly increasing during the $1940 \mathrm{~s}, 1950 \mathrm{~s}$, and early 1960s (from $0.1 \%$ in 1940 to $6.0 \%$ in 1965), and sharply increased during the 1960s, 1970s, and 1980s till 26.5\% in 1990. Women's smoking prevalence levelled off at approximately $26 \%$ until the early 2000 s, when it started to decrease slowly and reached $20 \%$ in $2011^{3-5}$.

While it is clear the curbing of smoking epidemic in women initiated in 2000 , a recent paper $^{6}$ using the same data, that from the Spanish National Health Interview Surveys, show a different trend. First and foremost, that paper is built on the statement that "In Spain, smoking rates are currently falling among men but they are still increasing among women", a statement which is not true currently, but remains in the "collective imaginary". Since more than a decade ago, smoking among Spanish women does not increase. We include here a chart with the available public data, including also the first Spanish Tobacco Survey from 1978 and the Spanish part of the European Health Survey of 2009 (Figure 1).

\section{Figure 1. Prevelance (\%) of daily smoking among adult ( $>15$ years) Spanish men and women, 1978 - 201116}

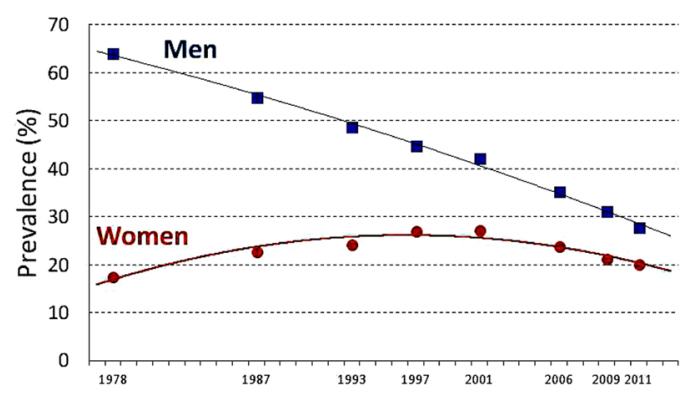

It is important to note that the influence of preventive policies in tobacco should not be restricted to price and warnings; since in Spain price and cost have complex relationships, caused by intensive smuggling in the 1990s and by the emergence of cheaper tobacco options (such as roll your own tobacco in recent years $)^{7-9}$. Powerful policies such as the ban of television advertising in $1988^{10}$ and in other media thereafter or the smoke-free legislation in 2005 and 2010 are important in any analyses of the influence of tobacco control measures in smoking prevalence rates, both in men and women ${ }^{11,12}$. A thorough review of the international and Spanish scientific literature on smoking and gender, including the abovementioned and other papers ${ }^{4,13-15}$ may inspire and guide prospective authors across the exciting and changing topic of women and tobacco control.

\section{REFERENCES}

1. Lopez AD, NE Collishaw, T Piha. A descriptive model of the cigarette epidemic in developed countries. Tob Control. 1994;3:242-7.

2. Thun M, Peto R, Boreham J, Lopez AD. Stages of the cigarette epidemic on entering its second century. Tob Control. 2012;21:96-101. doi: 10.1136/ tobaccocontrol-2011-050294
AFFILIATION

1 Agència de Salut Pùblica de Barcelona, Spain 2 Universitat Pompeu Fabra, Barcelona, Spain

3 Institut Catalò

d'Oncologia, Departament De Salut, WHO Collaborating Center for Tobacco Control, Barcelona, Spain 4 Universitat de Barcelona, Spain

CORRESPONDENCE TO Esteve Fernàndez, MD, $\mathrm{PhD}$

Institut Català d’Oncologia Tobacco Control Unit Gran Via de I'Hospitalet 199-203

08908 L'Hospitalet de Llobregat (Barcelona, Spain)

T: +34932607345 F: +34932607856 Email: efernandez@ iconcologia.net 


\section{Letter to the Editor}

3. Bilal U, Fernàndez E, Beltran P, Navas-Acien A, Bolumar F, Franco M. Validation of a method for reconstructing historical rates of smoking prevalence. Am J Epidemiol. 2014;179:15-9. doi: 10.1093/aje/kwt224. Epub 2013 Sep 27

4. Bilal U, Beltràn P, Fernàndez E, Navas-Acien A, Bolumar F, Franco M. Gender equality and smoking: a theory-driven approach to smoking gender differences in Spain. Tob Control. 2015. doi: 10.1136/tobaccocontrol-2014-051892

5. Instituto Nacional de Estadística. Encuesta nacional de salud 201112. Principales resultados. Nota de prensa. 2013. Available at: http:// www.ine.es/prensa/np770.pdf (accessed 2 March 2016)

6. Gil-Lacruz AI, Gil-Lacruz M, Leeder S. Women and smokingprices and health warning messages: evidence from Spain. Addict Behav. 2015;45:294-300. doi: 10.1016/j.addbeh.2015.01.016

7. Joossens L, Raw M. Progress in combating cigarette smuggling: controlling the supply chain. Tob Control. 2008;17:399-404.

8. Lopez Nicolàs A, Viudes de Velasco A. Possibilities and limitations of fiscal policies as health instruments: taxes on harmful consumption. SESPAS Report 2010. Gac Sanit. 2010;24 Suppl 1:85-9.

9. Fu M, Martínez-Sànchez JM, Clèries R, Villalbí JR, Daynard RA, Connolly GN, et al. Opposite trends in the consumption of manufactured and roll-your-own cigarettes in Spain (1991-2020). BMJ Open. 2014 Dec 10;4(12):e006552

doi: 10.1136/bmjopen-2014-006552

10. Shafey O, Fernàndez E, Thun M, Schiaffino A, Dolwick S, Cokkinides V. Cigarette advertising and female smoking prevalence in Spain, 1982-1997: case studies in International Tobacco Surveillance. Cancer. 2004;100:1744-9.

11. Perez-Rios M, Fernandez E, Schiaffino A, Nebot M, Lopez MJ. Changes in the prevalence of tobacco consumption and the profile of Spanish smokers after a comprehensive smoke-free policy. PLoS One. 2015;10:e0128305. doi: 10.1371/journal.pone.0128305

12. Villalbí JR. Assesment of the Spanish law 28/2005 for smoking prevention. Rev Esp Salud Pùblica. 83:805-20.

13. Amos A. Women and smoking. Br Med Bull. 1996;52:74-89. doi: 10.1093/oxfordjournals.bmb.a011534

14. U.S. Department of Health and Human Services. Women and Smoking: A Report of the Surgeon General. Rockville: U.S. Department of Health and Human Services, Public Health Service, Office of the Surgeon General; 2001.

15. Schiaffino A, Fernandez E, Borrell C, Salto E, Garcia M, Borras JM. Gender and educational differences in smoking initiation rates in Spain from 1948 to 1992. Eur J Public Health. 2003;13:56-60. doi: http://dx.doi.org/10.1093/eurpub/13.1.56

16. National Survey on Tobacco (1978); 1987-2006, 2011: |National Health Interview Surveys; 2011: European Health Interview Survey

CONFLICT OF INTEREST The authors have completed and submitted the ICMJE Form for Disclosure of Potential Conflicts of Interest and none were reported.

FUNDING

There was no source of funding for this research.

PROVENANCE AND PEER REVIEW

Not commissioned internally peer reviewed 